\title{
Improving the Contribution of Domestic Tourism to the Economy of Jordan
}

\author{
Dr. Mairna H. Mustafa \\ Queen Rania Institute of Tourism and Heritage/Department of Sustainable Tourism \\ The Hashemite University, P.O. Box 330127, Postal Code 13115 Zarqa, Jordan \\ Tel: 962-5-390-3333-5103Ｅ-mail: mairna@hu.edu.jo
}

Received: July 19, 2011

Accepted: September 21, $2011 \quad$ Published: February 1, 2012

doi:10.5539/ass.v8n2p49

URL: http://dx.doi.org/10.5539/ass.v8n2p49

\begin{abstract}
This paper aims at exploring the current status of domestic tourism in Jordan; tourism acts as a vital economic sector, though, revenues generated by domestic tourism are far below expected levels. Some obstacles are facing the growth of this market as the high cost of commercial accommodations, high cost of visiting tourism attractions, competing tour package offers by neighboring countries as Lebanon, Syria and Egypt, concentration of tourism development in some attractions, and most important the low levels of income for a big segment in the Jordanian society. This research explores the different factors affecting domestic tourism in Jordan, also its trends and attributes. Implications required to increase numbers and expenditures of domestic tourists were suggested.
\end{abstract}

Keywords: Domestic tourism, Tourism trends, National survey of domestic tourism market 2008, Jordan

\section{Introduction}

For Jordan, tourism is considered as the largest export sector, its second private sector employer, and a major producer of foreign exchange (Ministry of Tourism \& Antiquities [MOTA], 2003), it accounts for approximately $12.7 \%$ of the country's gross domestic product (GDP) (Central Bank of Jordan [CBJ], 2009). Tourism has generated 2,423 million JD in 2010 as revenue ( $1 \mathrm{JD}=1.408 \mathrm{USD}$ ), 42,034 jobs were offered as a direct employment by this sector (MOTA, 2011).

There are many strengths and opportunities that contribute to the fast growth of tourism sector in Jordan, these are: the wide range of tourism sites in urban, rural and remote areas, it encourages the sustainability of some basic cultural aspects as traditions and handcrafts, the great diversity of natural and cultural resources and destinations in Jordan, the fact that Royal Family of Jordan is well known all over the world and it has its wide range of international participation eventually giving a positive image for the country, the good climate with high possibility to provide destinations that will fulfill the needs of different markets of visitors all around the year, the high level of security and safety if compared to some other countries in the region suffering from political instability, the availability of tourism accommodations and facilities, the existing of unique and only of their kinds destinations as Dead Sea, Petra, Jesus Baptism Site and the Mosaic Map of Madaba, also the availability of health and wellness sites as hot springs and Dead Sea(JICA [Japanese International Cooperation Agency], 2004). Despite having all these advantages, there are some problems and threats facing this sector as having trips to Jordan being treated as an extension of neighboring countries in tour packages and trade, the concentration of tourism development and facilities in sometourism attractions, and the lack of promotional campaigns and marketing representatives abroad, (Roudan et al, 2000; JICA, 2004).

From a socioeconomic perspective, tourism is expectedto play a vital role in the economic prosperity and wellbeing of Jordanian society, this comes through providing tourism careers, as well as being a source of recreational activity; unfortunately the performance of tourism is below the expected level. The 2008 annual report issued by Jordanian Ministry of Labor [MOL] shows that workers in hotels and restaurants are forming only $2.3 \%$ of total employment in different economic activities; this goes parallel with the low levels of domestic tourism. Both of these problems are due to the unawareness of a big segment in Jordanian society about the importance of tourism and its activities, also the high cost of domestic tourism. Moreover; there is a lack of 
information about the performance of domestic tourism market; one of the few sources of data concerning such group comes from the Department of Statistics in MOTA; this data includes only the numbers of domestic tourists to main tourism sites and number of arrivals and nights in tourism accommodations. For Jordanians living abroad, the available data shows mainly their expenditures and length of stay. In 2008, the Department of Statistics [DOS] conducted for the first time a survey that covered Jordanian households who had tours within the country during that particular year, the survey revealed the characteristics, trends, preferences and trips' purposes of domestic tourists in Jordan. The data shows that the total expenditure by domestic tourists reached 61.4 million JD while the total revenue of tourism in the country is $2,088.3$ million JD, which indicates that the contribution of this market to total revenues gained by tourism is at its minimum levels.

\section{Objective of the Paper}

This paper aims at revealing the different attributes of domestic tourism market in Jordan (based on the National Survey of Domestic Tourism Market 2008), also exploring the factors behind the weak performance of this market, and finally suggesting implications to enhance levels of domestic market volumes and expenditures. It is important first to clarify the significance of the topic, and to give a general background about tourism attractions and markets in Jordan.

\section{Problems Facing Domestic Tourism Worldwide}

There is a significant contribution of domestic tourism to the development of any nation; the Manila Declaration of 1980 stated that: "within each country, domestic tourism contributes to an improved balance of the national economy through a redistribution of the national income. Domestic tourism also heightens the awareness of common interest and contributes to the development of activities favorable to the general economy of the country. Thus, the development of tourism from abroad should be accompanied by a similar effort to expand domestic tourism". The declaration also considered social aspects, since "The right toholidays, the opportunity for the citizen to get to know his own environment, a deeper awarenessof his national identity and of the solidarity that links him to his compatriots and the sense ofbelonging to a culture and to a people are all major reasons for stimulating the individual'sparticipation in domestic and international tourism, through access to holidays and travel".

There is a great role of domestic tourism in increasing tourism investments and tourist expenditures, decreasing the rates of unemployment, development of natural areas as parks since they form a suitable recreation place for families, decreasing seasonality and enhancing social bonds through VFR (Visiting Friends and Relatives) (Abu Rumman \& al-Rawi 2009). Domestic tourism brings about an intermingling of people from diverse social and cultural backgrounds as well as redistribution of spending power (Brian, 2002), domestic and regional tourists are important clients for self-employed sellers and owners of small establishments, this was evident in Yogyakarta (Indonesia) and elsewhere in South East Asia, where domestic and other Asian tourists tend to buy more from local vendors than Western tourists (Shah et al, 2002).

Despite the predominant role of domestic tourism in the total tourism activity, few studies discussed the significance and growth trends of such market, as well as the factors that affect its attributes; from these we list: urban residents' domestic tourism preferences and related themes (Song 2010; Jaakson 1986), effect of national economy growth on domestic tourism (Wen 1997), changes in consumer behavior and travel choices (Collins et al 2007; Sinton 2008; Becker 1987), determinants of domestic tourism demand (Massidda\&Etzo 2010; Athanasopoulos\& Hyndman 2008; Yap \& Allen 2010), benefits of participation in domestic tourism as an integration strategy concerning majority-minority relationships (Moufakker 2010), and role of tourism as a major player in the regional development (Seckelmann 2002).

The significance of domestic tourism is still invisible due to the lack of commonly accepted and used definitions of domestic travel, another reason is that the available domestic tourism data is mostly in the form of number of trips to destinations beyond a certain minimum distance from the normal place of residence, such trips are involving at least one overnight stay, another form of data includes same-day visitors; moreover, VFR trips are in most cases excluded in recording the number of these domestic tourists (Eijgelaar et al 2008). Domestic tourism is often regarded as being less profit-generating to the national economy if compared to inbound tourism since it does not generate foreign currency; it actually redistributes domestic currency spatially within boundaries of a country, and not all domestic tourists use commercial accommodation (McKercher 2000). The volumes of domestic tourists if compared to international ones are low in some countries; this is due tothe high relative value of local currency against hard currencies enticing then more locals to travel abroad, the growth in low cost airlines flying from domestic tourists' country to destinations overseas, the lack of package holidays for sale in the country of domestic tourists, lack of awareness and understanding by locals of the excellent visitor 
destination their home country is and the range of accommodation options and attractions available (Tourism Industry Association of New Zealand 2006). Other factors that affect volumes of domestic tourism are: the richness of tourists' generating country with tourism resources, its size and distribution of population, the proximity to other countries, the size and number of geopolitical divisions, level of national pride held by the local community, and restrictions on authorization of travel visas (McKercher 2000). Most of these factors apply to the case of Jordan, causing then the low volumes of domestic tourism compared to both inbound and outbound tourism; this will be discussed in the following sections of this paper.

\section{Tourism Attractions and Markets in Jordan}

The total area of Jordan is $88,778 \mathrm{sq}$. $\mathrm{km}$, ithas a population of 5,980,000 with being divided into three main regions; the central region with an area of 14,399 sq. km and it includes the governorates of Amman (the capital), Balqa, Zarqa and Madaba; the northern region with an area of 28,943 sq. km and it includes the governorates of Irbid, Mafraq, Jarash and Ajloun; and the southern region with an area of 45,436 sq. km and it includes the governorates of Karak, Tafila, Ma'an and Aqaba. Map 1 shows the locations, areas and populations of these governorates. Although the southern region has the majority of kingdom's area (51.2\%), it has the least population density, which is the contrary to the central and northern governorates (DOS 2009).Tourism resources in Jordan are so diverse although of being located within a smallarea, these resources can be classified into the following three general categories:

1) Natural Resources: these include areas of significant land/seascapes as: Aqaba, Wadi Rum and natural reserves scattered all over the country.

2) Cultural Resources: these include mainly archaeological/historical sites, shopping and galleries, events, and handcrafts.

3) Therapeutic Resources: these are the Dead Sea and some locations where waterfalls and hot springs are found.

Niche tourism markets in Jordan attracted to these sites are: cultural/heritage, ecotourism, religious, sport/adventure, and MICE (Meetings, Incentives, Conferences and Events) (MOTA 2003). Table 1 gives a brief description of main tourism attractions within each governorate; while Map 2 shows the locations of these major attractions.

\section{Domestic Tourism Trends in Jordan}

\subsection{The National Survey}

According to the National Domestic Survey of 2008, the total number of households in Jordan was 1,045,000, of which $21.4 \%$ conducted tourism trips within the country. The number of trips during that year reached 1,209,231; about $33 \%$ of these trips were by households living in the capital, $21 \%$ in Irbid, $18 \%$ in Zarqa, $11 \%$ in Balqa, $4 \%$ in Aqaba and $13 \%$ for other governorates. The total number of same day trips reached 951,000 trips $(78.6 \%$ of total domestic trips), while 259,000 trips were overnight ones.

\subsubsection{Purpose of the Trip}

The average number of individuals for each trip was 3.7 (3.8 for same day trips and 3.3 for overnight trips), the survey has shown that $57 \%$ of the same day trips were for recreation and holidays, while $32 \%$ were for visiting friends and relatives (VFR), $8 \%$ were for school, universities and colleges trips, $2 \%$ for shopping and less than $2 \%$ for other purposes (these include business, religious purposes, medical treatment, conference, training, etc...). For overnight trips, $55 \%$ of the trips were for VFR, 39\% for recreation, $2 \%$ for business and $3 \%$ for other purposes.

\subsubsection{Total expenditure}

The total expenditure of domestic tourists reached 61.4 million JD in 2008; $55.3 \%$ of this expenditure was for overnight trips (32.7 million JD), while 46.7\% (28.7 million JD) was for same day trips. Most of this expenditure was by households living in the capital (Amman) with a percentage of $46.7 \%$, followed then by Zarqa (13.2\%), Irbid (12.6\%), Aqaba (10\%), Balqa (7.1\%) and $15.5 \%$ for other governorates.

Considering the purpose of spending; recreation and short feasts holidays had the share of $64.8 \%$ (40 million JD), $25.9 \%$ for VFR, $4.9 \%$ for shopping and $4.4 \%$ for other purposes (business, training, medical treatment, religious visits, conference, school/colleges trips ....etc). .

The average daily spending for the trip was 51 JD (it was 30 JD in same day trips and 127 JD for overnight trips). Individual wise, the average spending for one day trip was $8 \mathrm{JD}$, while overnight trips had the average spending of $10 \mathrm{JD}$ for each domestic tourist. 
The total expenditure was spent in the governorates of Jordan as follows: $38 \%$ in Aqaba, $20 \%$ in the Capital, $14 \%$ in Balqa, $10 \%$ in Irbid, and $18 \%$ was in other governorates. Generally, $44 \%$ of the total expenditure was spent in the southern region, $39 \%$ in the central region and $17 \%$ in the northern region.

For the average spending per trip; it was found that the highest value was in the governorate of Aqaba (120.5 JD), followed then by Jerash (109.1 JD), Ma'an (83.5 JD), Karak (67.3 JD), the Capital (63.2 JD), Mafraq (59.7 JD), Tafilah (51.6 JD), Ajloun (46.2 JD), Zarqa (36.9 JD), Balqa (33.4 JD), Madaba (33.2 JD), and Irbid (31 JD).

\subsubsection{Accommodations}

The total number of overnight trips was 259,000 trips in $2008 ; 13 \%$ of these trips were spent in hotels and hotels suites, $15 \%$ were in rented apartments, $60 \%$ in private homes of friends and relatives, $5 \%$ in second homes owned by the tourists and $6 \%$ in other accommodations (e.g. camps). The average of stay was 3.9 nights in general (2.3 nights in hotels and hotel suites, and 2.7 nights for rented apartments).

\subsubsection{Seasonality}

Most of the trips took place during the months October-December (33\%); while $27 \%$ were in the months of January-March, $22 \%$ in the months of July-September, and $18 \%$ for months April-June. The same applies to expenditure, the months October-December had the share of $27 \%$, followed then by months April-June with a percentage of 26\%, 24\% for January-March and 23\% for July-September.

\subsubsection{Distances \& Locations of Trips}

The results of the survey have shown that trips with a crossed distance less than $20 \mathrm{~km}$ from the place of residence formed $23 \%$ of total number of trips, while $24 \%$ were for trips with the distance of $21-40 \mathrm{~km}, 25 \%$ for trips with the distance of $41-80$ and $28 \%$ for trips with a distance more than $81 \mathrm{~km}$.

It was found that $69 \%$ of the trips conducted by households living in the central region were to the same region, while $16.2 \%$ were to northern region and $14.9 \%$ were to southern region. For the households living in the northern region, $57 \%$ of their trips were to the same region, $36 \%$ to the central region and $8 \%$ to the southern region. Most of the trips of households living in the southern region were to the same region $(58 \%), 31 \%$ to the central region and $11 \%$ to the northern region.

The results of the survey revealed that $36 \%$ of the same day trips were to the capital, $18 \%$ to Balqa, $10 \%$ to Zarqa and Madaba, $17 \%$ to Irbid, $11 \%$ to Jerash, Ajloun and Mafraq, and 9\% was for the governorates of the southern region. For overnight trips, $38 \%$ of these were to Aqaba, $19 \%$ to the Capital, $13 \%$ to Irbid, $12 \%$ to Zarqa and Balqa, and $18 \%$ to other governorates.

\subsubsection{Transportation}

The survey has shown that the 1,209,231 trips for 2008 were distributed as follows in terms of transportation means used: $66.7 \%$ by private automobiles, $31.11 \%$ by public transportation, $0.52 \%$ by rented cars, $0.08 \%$ by airplanes, and $1.5 \%$ by other means. For the same day trips (with a total of 950,725 ), $69.63 \%$ of the trips were by private automobiles, 28.51 by public transportation, $0.34 \%$ by rented cars, $0 \%$ by airplanes, and $1.52 \%$ by other means of transportation. The overnight trips (with a total of 258,506) had the following distribution: $56.36 \%$ by private automobiles, $40.67 \%$ by public transportation, $1.17 \%$ by rented cars, $0.37 \%$ for airplanes, and $1.43 \%$ by other means of transportation.

\subsubsection{Satisfaction}

Regarding the general satisfaction of domestic tourist with tourism facilities provided; the survey had the following evaluations: for roads and means of transportation ( $43.5 \%$ excellent, 47.9 good, $6.6 \%$ acceptable, $1.6 \%$ weak, and $0.4 \%$ very weak); for tourism amenities (31.8\% excellent, $46.3 \%$ good, $10.1 \%$ acceptable, $7.8 \%$ weak, and $4.0 \%$ very weak); and for facilities and services within these sites $(32.0 \%$ excellent, 47.3 good, $10.6 \%$ acceptable, $6.7 \%$ weak, and $3.4 \%$ very weak).

\subsection{Trips within Governorates}

(Note: the attractions mentioned below are all explained in Table 1)

\subsubsection{Capital Govenorate}

The number of trips to the Capital governorate reached 389,000 trips of which $44.7 \%$ were for recreation and $55.3 \%$ for other purposes. The distribution of these trips according to the location was as follows: $12.9 \%$ to al-Hussein Gardens, $6.9 \%$ to Amman National Park, 5.7\% to Ghamadan Park, 8.8\% to to Luna Parks and other gardens (as al-Hussein Gardens), 2.6\% to Iraq al-Amir and Hisban, $0.4 \%$ to Roman Theater and Amman Citadel, and $62.7 \%$ to other sites. 


\subsubsection{Balqa Governorate}

There were 182,000 trips to Balqa governorate in $2008 ; 71.7 \%$ were for recreation and $28.3 \%$ were for other purposes. Thse trips were distributed as follows: $47.9 \%$ to Dead Sea, $4.4 \%$ to Wadi Shu'ib, $1.2 \%$ to Rmimin Waterfalls, $0.5 \%$ to Jesus Baptism Site, $45.9 \%$ to other sites.

\subsubsection{Zarqa Governorate}

The Governorate of Zarqa had the total of 88,000 trips in $2008,38 \%$ of these were for recreation, and $62 \%$ for other purposes. Total number of trips was distributed as follows: $0.3 \%$ to Azraq Reserve, $5.2 \%$ to 'Alouk, $4.5 \%$ to Beren, and $90 \%$ to other sites.

\subsubsection{Madaba Governorate}

For the Governorate of Madaba; there were 27,000 trips of which 57\% were for recreation and $43 \%$ were for other purposes. These were distributed as follows: $23.9 \%$ to Ma' in Waterfalls, $6.3 \%$ to Siyagha and Mount Nebo, $0.5 \%$ to Mosaic Map Church, $0.5 \%$ to Macherus and $56.3 \%$ to other sites.

\subsubsection{Irbid Governorate}

The governorate of Irbid had 190,000 trips in 2008; $49.0 \%$ of these trips were for recreation and 51\% were for other purposes. These trips were distributed as follows: 6.3\% to Umm Qais, 5.8\% to Himmeh Hot Springs, 4.4\% to Ramtha, $2.2 \%$ to Birqish, $1.4 \%$ to Pella, and $80.1 \%$ to other sites.

\subsubsection{Mafraq Governorate}

The trips to the governorate of Mafraq were 21,000 in 2008; $13.7 \%$ of these trips were for recreation while $86.3 \%$ were for other purposes. No records are available for domestic tours to specific sites.

\subsubsection{Jerash Governorate}

There were 59,000 domestic tours to the governorate of Jerash; of these $59.3 \%$ were for recreation and $40.7 \%$ were for other purposes. $89.7 \%$ were to the archaeological city and its surroundings while $10.3 \%$ were to the pine forests of Dibbin.

\subsubsection{Ajloun Governorate}

In 2008, the total number of domestic tours to the governorate of Ajloun reached 44,000 trips; $51.6 \%$ of these trips were for recreation and $48.4 \%$ were for other purposes. $92.2 \%$ of the domestic tours were to the town and pine forests, the ones to Ajloun Castle had the share of 7.8\%.

\subsubsection{Karak Governorate}

The governorate of Karak had the total of 34,000 domestic tours; $38.1 \%$ of these trips were for recreation and $61.9 \%$ for other purposes. $38.0 \%$ of these trips were to Southern Ghors, only $0.4 \%$ of the trips were to Karak Castle.

\subsubsection{Tafilah Governorate}

There were 18,000 trips to this governorate; $42.2 \%$ of these trips were for recreation while $57.8 \%$ were for other purposes. The Natural Reserve of Dana had $20.7 \%$ of these trips, 11.5 were to Afra Springs and $67.8 \%$ were for other sites in the governorate.

\subsubsection{Ma'an Governorate}

The domestic trips to the Governorate of Ma'an reached the total of 19,000 trips, $46.1 \%$ of these trips were for recreation and $53.9 \%$ were for other purposes. The site of Petra had the share of $59.7 \%$ of these trips, while Shobak had $10.8 \%$, and other sites had $29.4 \%$.

\subsubsection{Aqaba Governorate}

During 2008, Aqaba Governorate had the total of 138,000 domestic trips; $76.3 \%$ of these were for recreation while $23.7 \%$ were for other purposes. $99 \%$ of domestic tourists who visited the governorate went to the city of Aqaba; only $1 \%$ went to Wadi Rum.

\section{Problems Facing Domestic Tourism in Jordan}

The National Survey of Domestic Tourism for the year 2008 stated that 38,566 households did not have tourism trips; these households justified this by not having the interest or suitable conditions (65.3\%), not having means of transportation available all the time to tourism attractions (7.8\%), the high cost of accommodations (3.4\%), the high cost of visiting tourism attractions $(2.8 \%)$, the high cost of using services in these attractions $(2.3 \%)$, less than $1 \%$ mentioned the competing offers by neighboring countries (it should be considered that outbound 
tourists who went to these neighboring countries as Lebanon, Syria and Egypt are not included in the National Survey), and $17.5 \%$ for low income levels and other reasons.

According to the statistics of MOTA (2010); the number of Jordanian outbound tourists reached 2,916,632, which is $42 \%$ more than the total number of $2009(2,054,369)$. By comparing the number of inbound tourists of Jordan in $2010(8,247,135)$ to the number of outbound tourists, it can be indicated that Jordan is losing a market of a great potential. There are different factors behind such leakage; one of them is the high cost of domestic tourism activities and services if compared to nearby countries as Egypt, Syria and Lebanon. Moreover, most of tourism attractions in Jordan are located in the southern region of the country, while most of the population is concentrated in the northern and central regions, which makes the distance to neighbor countries as Lebanon and Syria less if compared to the distance to the southern region. Also, most of Jordanian tourists are interested in short daily trips to parks during the year, they tend to spend night at hotels during feasts for few days, the majority of attractions in Jordan are cultural/heritage sites, of which most are located in areas lacking recreational and nightlife activities (MENAFN 2009). An indicator to be considered is that till 2009, the total number of tour operating offices and travel agencies in Jordan reached 480, only $8 \%$ of these are located outside Amman (the capital); the number of inbound tour operators is 142 , while outbound tour operators are 24 , tour operators who organize domestic trips are only 20 (al-Shomali, 2011). There is also the attitude of hotels' owners toward domestic tourism; they do not tend to give good offers to encourage this market if compared to the offers given to inbound tourists, even with the continuous efforts by Jordanian government through decreasing taxes to reduce rates of these hotels (Ammari, 2009). Not less important is the negative relative change seen in the numbers of domestic tourists to most of tourism attractions in Jordan for the years 2009/2010, which is not the case of inbound tourists; according to the statistical bulletin of MOTA for 2010, the relative change in the numbers of tourists was as follows in different sites for inbound and domestic tourists respectively: Petra (32.5\%, -6.2\%), Jerash $(26.7 \%,-4.1 \%)$, Um Qais (14\%, -12.8\%), Mount Nebo (30\%, 14.7\%), Ajloun (24.5\%, 20\%), Madaba Mosaic Map Church (44.9\%, 21.8\%), Wadi Rum $(59.9 \%, 304 \%)$, Karak $(20.4 \%,-14.4 \%)$, Jesus Baptism Site $(22 \%,-5 \%)$, Dead Sea $(-0.1 \%$, $-13 \%)$, QusayrAmra (19.2\%, -25.5\%), Shobak (26\%, -19.4\%), Afra (-5.8\%, -29.5\%), Folklore Museum (15.4\%, -5.4\%), Jordan Museum (76\%, 33.6\%), and Aqaba Museum (-14.7\%, -44.1\%). In most of these cultural/heritage sites, lack of services and facilities is playing a vital role in the decrease of tourists' numbers.

\section{Conclusions}

Tourism acts in Jordan as a vital source of economy; though, there is still a focus on international tourism markets, this is witnessed in offers given by different tourism sectors and in measuring the different attributes of the market through statistical data. There should be more efforts by authorities (as Ministry of Tourism and Antiquities and Department of Statistics) to conduct more surveys that aim at understanding the different trends and needs of domestic tourism markets. As mentioned above, there is only one national survey that was conducted in 2008 concerning domestic tourism in Jordan.

It can be noticed from the results of National Survey of Domestic Tourism Market for 2008 that most of the trips are one-day trips $(78.6 \%) ; 57 \%$ of these trips were for recreation, which mostly take place in parks and other natural areas, while for overnight trips (21.4\% of total trips), 55\% of these were for VFR, and $39 \%$ are for recreation. It becomes necessary then to focus on encouraging domestic tourists to have more overnight trips; this becomes possible by taking a different attitude by hotels and other commercial accommodations through better rates that suit domestic tourists' level of spending, another implication to be considered is providing areas where attraction are located with recreational and nightlife activities. Despite the high satisfaction of domestic tourism concerning transportation and different services, the high price issue becomes an obstacle for this market. Sindiga (1996) suggested that creating small and medium sized hotels in the rural areas throughout a country would help in attracting domestic tourists, this can be applied to the case of Jordan, especially that most of tourism attractions are located in rural and remote areas.

Most of the expenditure by domestic tourists was spent in the southern region (especially in Aqaba during feasts) with a percentage of $44 \%$, while $39 \%$ was in central region, and $17 \%$ was in the northern region; moreover, sites of cultural/heritage values have the least visitation and spending by tourists, most of these sites lack tourism development (facilities and interpretation), the deconcentration of facilities should be considered in order to attract domestic tourists during the whole year. More promotion and awareness about these sites and how to behave in them should be spread among different segments of Jordanian society. Another implication to be considered is developing programs for family tourism since it forms a significant group of domestic market. Spreading awareness about working in tourism and its benefits, also its contribution to local economy through media and educational programs would help in increasing the willingness of Jordanians to get enrolled in tourism careers, consequently more promotion for tourism attractions and facilities. Besides all previously 
suggested implications, a national domestic tourism strategy should be formulated to give a clear direction and framework for enhancing the level of domestic tourism, especially in less developed governorates; this will offer new destinations while being a development factor in them. According to Seckelmann (2002), stable prices and strong promotion of new destinations are essential to achieve sustainable development in disadvantaged regions of a country.

\section{References}

al-Majali, N. (2009). Archaeological Surveys in al-'Aluk and al-Masarrat Reveal a Bronze Age Occupation, published in al-Rai Newspaper, issue of September 30, 2009. [Online] Available: http://www.alrai.com/pages.php?from_date $=1 \&$ searchtext $=\% \mathrm{C} 7 \% \mathrm{E} 1 \% \mathrm{DA} \% \mathrm{C} 7 \% \mathrm{E} 1 \% \mathrm{E} 6 \% \mathrm{DF} \& \mathrm{btnsearch} . \mathrm{x}=3 \&$ btnsearch.y $=5$ (July $\left.12^{\text {th }}, 2011\right)$

al-Mirayat. (2008). Springs of 'Afra and Burbeeta in Tafilah start to Receive Tour Groups, published in ad-Dostur Newspaper, issue of February 21 ${ }^{\text {st }}$ 2008. [Online] Available: http://www.addustour.com/ViewTopic.aspx?ac=\%5CLocalAndGover\%5C2008\%5C02\%5CLocalAndGover_iss ue134_day21_id27645.htm (July 12 $\left.2^{\text {th }}, 2011\right)$

Ammari, T. (2009). Domestic Tourism Again, published in a-Rai Newspaper, issue of May $21^{\text {st }}, 2008$. [Online] Available: http://alrai.com/pages.php?articles_id=28188 (May 21, 2009)

Archer, B. (1978). Domestic Tourism as a Development Factor. Annals of Tourism Research, 5 (1), $126-141$. http://dx.doi.org/10.1016/0160-7383(78)90007-5

Becker, Ch. (1986). Domestic Tourism in FRG: Trends and Problems. Annals of Tourism Research, 14 (4), 516-530. http://dx.doi.org/10.1016/0160-7383(87)90068-5

CBJ. (2009). The Real Sector Report, a report issued by Central Bank of Jordan [CBJ]. [Online] Available: http://www.cbj.gov.jo/uploads/chapter1.pdf (March 22, 2011)

Collins, D., Galliano, K., Quinn, T., Faiweather, P., Maurer, A., Childs, C. \& White, B. (2007). Changing Consumer Behavior: Impact on the Australian Domestic Tourism Market. A consultancy project for the Department of Industry, Tourism and Resources Report by Tourism Research Australia and the Travel Research Centre.

DOS. (2008). National Survey of Domestic Tourism in Jordan, a report prepared by the Jordanian Department of Statistics. [Online] Available: http://www.dos.gov.jo/na/na_a/tour_2008/surv2008.pdf (June $7^{\text {th }}, 2011$ )

DOS. (2009). Jordan in Numbers, a report prepared by the Jordanian Department of Statistics [DOS]. [Online] Available: http://www.dos.gov.jo/dos_home/dos_home_a/main/jorfig/2009/jor_f_a.htm (June $\left.7^{\text {th }}, 2011\right)$

Eijgelaar, E., Peeters, P. \& Piket, P. (2008). Domestic and International Tourism in a Globalized World; Research in Progress Paper presented at the International Conference "Ever the twain shall meet - relating international and domestic tourism" of Research Committee RC50. International Tourism, International Sociological Association Jaipur, Rajasthan, India, November, 24 - 26, 2008.

el-Roudan, O., al-Ardah, F. \& Bedour, T. (2000). Tourism Economics in Jordan: Essential Facilities and Marketing. Amman: Royal Scientific Society.

Jaakson, R. (1986). Second-home Domestic Tourism. Annals of Tourism Research, 13 (3), $367-391$. http://dx.doi.org/10.1016/0160-7383(86)90026-5

JICA. (2004). Comprehensive Basic Survey on Priority Areas of JICA Assistant, a report by: Japanese International Cooperation Agency.

Massidda, C. \& Etzo, I. (2010). Domestic tourism demand in Italy: a Fixed Effect Vector Decomposition Estimation, issued by: Munich Personal RePEc Archive, Paper No. 26073, posted 21. October 2010. [Online] Available: http://mpra.ub.uni-muenchen.de/26073/ (July $7^{\text {th }}, 2011$ )

MENAFN. (2009). Experts Recommending Taking Procedures by Private Sector to Encourage Domestic Tourism in Jordan, issued by Middle East \& North Africa Financial Network [MENAFN], issue of March 24, 2009. [Online] Available: http://www.menafn.com/arabic/qn_print.asp?StoryID=1093240297\&subl=true (May 21, 2009)

MOL. (2008). Annual Report of Jordanian Ministry of Labor [MOL], [Online] Available: http://www.mol.gov.jo/Portals/0/Annual\%20Report/annual\%20report\%202008.pdf (March 26, 2009) 
MOTA. (2003). National Tourism Strategy (2004-2010), issued by Ministry of Tourism \& Antiquities [MOTA]. [Online] Available: http://www.tourism.jo/inside/Strategy.asp (April 10, 2006)

MOTA. (2011). The Tourism Statistical Bulletin-Volume 7, issued by issued by Ministry of Tourism \& Antiquities [MOTA]. [Online] Available: http://www.tourism.jo/ar/Default.aspx?tabid=120 (June 2, 2011)

Moufakkir, O. (2010). Peace through Domestic Tourism and Tourism Rights: Inclusion of Muslim Ethnic Minorities in the Context of Social Tourism. The Journal of Tourism and Peace Research, 1(1), 42- 59.

Samawi, H. (2008). Tourism in Jordan: A Geographical Study. Amman: Ministry of Culture.

Seckelmann, A. (2002). Domestic Tourism- A Chance for Regional Development in Turkey. Tourism Management, 23, 85-92. http://dx.doi.org/10.1016/S0261-5177(01)00066-8

Shah, K., McHarry, J. \& Gardiner, R. (2002). Sustainable Tourism: Turning the Tide, an economic briefing paper in Towards Earth Summit 2002 Project, Paper No.4. [Online] Available: http://www.stakeholderforum.org/fileadmin/files/SF_Briefing_Papers/bp_tourism.pdf (July 15, 2011)

Shomali, I. (2011). Citizens Prefer Outbound Tourism and Consider it Cheaper. Published in al-Ghad Newspaper, issue of May $3^{\text {rd }}$ 2011. [Online] Available: http://www.alghad.com/index.php/article/180369.html (June 7, 2011)

Sindiga, I. (1996). Domestic Tourism in Kenya. Annals of Tourism Research, 23 (1), 19-31. http://dx.doi.org/10.1016/0160-7383(95)00040-2

Sinton, J. (2008). Domestic Tourism Audit: Insights into Australian's Domestic Travel Behavior, Barriers and Motivations, a report published by Advance Tourism, Australia. [Online] Available: http://www.takeabreak.com.au/Files/GB_Domestic_Tourism_Audit_07_advance_tourism.pdf (June $\left.7^{\text {th }}, 2011\right)$

Song, Y. (2010). On Domestic Tourism Preferences of Urban Residents in China. International Journal of Marketing Studies, 2(2): 283-286.

Teller, M. (2006). The Rough Guide to Jordan. New York: Rough Guides.

Wen, Z. (1997). China's Domestic Tourism: Impetus, Development and Trends. Tourism Management, 18(8), 565-571. http://dx.doi.org/10.1016/S0261-5177(97)00082-4

WTO. (1980). Manila Declaration on World Tourism, The World Tourism Conference, HELD at Manila, Philippines, from 27 September to 10 October 1980, convened by the WorldTourism Organization. [Online] Available: http://www.univeur.org/CMS/UserFiles/65.\%20Manila.PDF (June 7, 2011)

Yap, Gh. \& Allen, D. (2011). Investigating other Leading Indicators Influencing Australian Domestic Tourism Demand. Mathematics and Computers in Simulation, 81, 1365-1374. http://dx.doi.org/10.1016/S0261-5177(97)00082-4

. (2006). Domestic Tourism Marketing: Recommendations for Ongoing Work, a report issued by Tourism Industry Association of New Zealand, [Online] Available: http://www.tianz.org.nz/content/library/SB0406MarketingPaper.pdf (June 7, 2011)

(2011). Key to the Kingdom: Tourism Sites. [Online] Available:

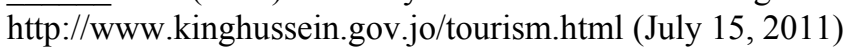


Table 1. Main Tourism Attractions in Jordanian Governorates

\begin{tabular}{|c|c|c|}
\hline Governorate & Location & Significance \\
\hline \multirow[t]{4}{*}{ Capital } & Amman & $\begin{array}{l}\text { It is the capital of Jordan and has the lion share of services and facilities, } \\
\text { there are many attractions in this city such as: the Roman Theater and } \\
\text { Odium in the downtown dated to the period (161-169 A.D.), also Amman } \\
\text { Citadel, an archaeological site that has remains of several periods, it is } \\
\text { famous for the Roman Temple of Hercules, and the Umayyad city. Many } \\
\text { art galleries are in Amman, a good example is Darat al-Funun, which is } \\
\text { housed in avilla dated to the 1920's, also the National Archaeological } \\
\text { Museum with its rich collection of antiquity, and Folklore Museums in } \\
\text { Roman Theater, composing of panoramas reflecting the traditional } \\
\text { heritage of Jordan. (1)There are also pine forests parks and themed } \\
\text { gardens as al-Hussein Gardens located on the outskirts of Amman.(5) }\end{array}$ \\
\hline & Hisban & $\begin{array}{l}\text { The Biblical Hishbon, the capital of Amorites, settled during different } \\
\text { archaeological periods, main remains are the Hellenistic wall of the city, a } \\
\text { Roman fort, a Byzantine church, and Mamluk tombs. }(2)\end{array}$ \\
\hline & Iraq al-Amir & $\begin{array}{l}\text { Qasr el-Abd is a Hellenistic huge palace, with its remarkable lion stone } \\
\text { carvings on its corners; there are also the caves of Iraq al- Amir that were } \\
\text { used as stables and for storage. (1) }\end{array}$ \\
\hline & Umm ar-Rasas & $\begin{array}{l}\text { Biblical Meefa', it was settled during Iron, Nabataean, Roman, and } \\
\text { Byzantine Periods, main remains are the Nabataean water wells, Roman } \\
\text { fort and towers, Byzantinesettlements and churches, mosaics and tower. } \\
\text { (2) }\end{array}$ \\
\hline \multirow[t]{5}{*}{ Balqa } & Dead Sea & $\begin{array}{l}\text { Dead Sea is distinguished for being the lowest point on earth }(400 \mathrm{~m} \\
\text { below sea level) and for its extensively salty water; it is } 75 \text { kilometers long } \\
\text { and from } 6 \text { to } 16 \text { kilometers wide. It is fed by the Jordan River, but it has } \\
\text { no outlet. It contains } 350 \text { grams of salt per kilogram of water, as compared } \\
\text { to about } 40 \text { grams in the world's oceans. (3) }\end{array}$ \\
\hline & $\begin{array}{l}\text { Baptism Site of } \\
\text { Jesus the Christ }\end{array}$ & $\begin{array}{l}\text { It is located on the eastern bank of Jordan River; main features are the } \\
\text { Churches of John the Baptist, Elijah's Hill Monastery and John the Baptist } \\
\text { Spring. (1) }\end{array}$ \\
\hline & Salt & $\begin{array}{l}\text { Salt is distinguished with its Ottoman architecture in the classical style. } \\
\text { Mainly recognizable are the Ottoman houses with their long-arched } \\
\text { windows; Salt is also the final resting place of the Prophet Ayyoub (Job). } \\
\text { (3) }\end{array}$ \\
\hline & Wadi Shu'ib & $\begin{array}{l}\text { Prophet Shu'ayb (Jethro), the Midianite father-in-law of Prophet Musa } \\
\text { (Moses) is said to be buried in a tomb near Salt in Wadi Shu'ayb. (3) }\end{array}$ \\
\hline & Rmimin & Distinguished for its waterfalls and ancient olive presses. \\
\hline \multirow[t]{4}{*}{ Zarqa } & Natural Reserves & $\begin{array}{l}\text { The Shomari Wildlife Reserve covers } 22 \text { square kilometers. Numerous } \\
\text { species of wildlife, including ostrich, gazelle, wild donkey, Arabian oryx } \\
\text { and others inhabit Shomari (2). There is also Azraq Wetland Reserve, a } \\
\text { location of rich biodiversity, providing a natural habitat for different } \\
\text { species, including the Azraq Killifish Aphaniussirhani, the only true } \\
\text { endemic vertebrate species of Jordan. (1) }\end{array}$ \\
\hline & Umayyad Palaces & $\begin{array}{l}\text { The Eastern Desert: it includes the beautiful 8th century A.D. palaces built } \\
\text { by the Umayyad Caliphs for hunting and resting, one of them is Qusayer } \\
\text { Amra with its beautiful frescoes; also QasrHarranah with its stone built in } \\
\text { mortar architecture. (1) }\end{array}$ \\
\hline & Qasr el-Azraq & $\begin{array}{l}\text { A large black fortress that dates back to the beginning of the } 13 \text { th century } \\
\text { CE. Built from local black basalt rocks, the castle exploited Azraq's } \\
\text { important strategic position and water sources. The first fortress here is } \\
\text { thought to have been built by the Romans around } 300 \mathrm{CE} \text {, during the reign } \\
\text { of Diocletian. (2) }\end{array}$ \\
\hline & ‘Alukand Beren & $\begin{array}{l}\text { These were settled during Late Bronze Age, Iron Age, Roman, Byzantine, } \\
\text { Umayyad and Ottoman Periods. It includes agricultural settlements, }\end{array}$ \\
\hline
\end{tabular}




\begin{tabular}{|c|c|c|}
\hline & & churches, olive presses, and traditional houses. (4) \\
\hline \multirow[t]{4}{*}{ Madaba } & Madaba City & $\begin{array}{l}\text { Madaba's most famous mosaic is located in the Church of St. George in } \\
\text { the middle of town. The Mosaic Map of Palestine represents the Holy } \\
\text { Land and its surrounding regions.At the southern entrance to Madaba, near } \\
\text { the King's Highway, is the Church of the Apostles, it dates to } 578 \text { CE. (2) }\end{array}$ \\
\hline & Macherus & $\begin{array}{l}\text { Herod the Great's ancient fortress, located by the village of Makawer. } \\
\text { There, it is said, the beautiful Salomé danced for Herod Antipas, who } \\
\text { presented her with the head of the Prophet Yahya or John the Baptist to } \\
\text { honor her wishes. (2) }\end{array}$ \\
\hline & Ma'in & $\begin{array}{l}\text { Known for the thermal mineral springs of nearby Zarqa Ma'een, which } \\
\text { hosts a therapeutic health spa. (2) }\end{array}$ \\
\hline & Mount Nebo & $\begin{array}{l}\text { According to Bible; it was the spot where Prophet Moses died after he saw } \\
\text { the Promised Land.There are two peaks on Mt. Nebo, Siyagha and } \\
\text { al-Mukhayyat. During the sixth century CE, a Byzantine monastery was } \\
\text { constructed at Siyagha. (2) }\end{array}$ \\
\hline \multirow[t]{4}{*}{ Irbid } & Um Qais & $\begin{array}{l}\text { Um Qais is a Decapolis city, distinguished for its beautiful Roman and } \\
\text { Byzantine structures built of both basalt and limestone, also for the } \\
\text { Ottoman village located there. (1) }\end{array}$ \\
\hline & Pella & $\begin{array}{l}\text { A Decapolis city that includes a first century CE Roman Odeon, or theater. } \\
\text { Next to this are the ruins of a large Byzantine church, built in the sixth and } \\
\text { seventh centuries on top of a Roman shrine. The remains of Roman baths } \\
\text { are also visible in this area. To the south is Tel Husn, on top of which was } \\
\text { a Byzantine fortress. (2) }\end{array}$ \\
\hline & Irbid & $\begin{array}{l}\text { Irbid is the industrial center and administrative capital of the north. The } \\
\text { city has a good selection of restaurants, a number of banks and hotels, and } \\
\text { the campus of Yarmouk University. Artifacts and graves in the area show } \\
\text { that Irbid has been inhabited since the Bronze Age. Under Roman rule, the } \\
\text { city was renamed Arbila. (2) }\end{array}$ \\
\hline & Himmeh & $\begin{array}{l}\text { Famous since Roman Period for its hot springs, the main hot spring has } \\
\text { mineral-rich waters with a temperature of } 57^{\circ} \mathrm{C} \text {. (2) }\end{array}$ \\
\hline Mafraq & Umm el-Jimal & $\begin{array}{l}\text { Umm al-Jimal is known as the Black Oasis because of the black basalt } \\
\text { rock from which many of its houses, churches, barracks and forts were } \\
\text { built. (2) }\end{array}$ \\
\hline \multirow[t]{2}{*}{ Jerash } & Jerash City & $\begin{array}{l}\text { Jerash is one of the Decapolis cities, and is considered as one of the most } \\
\text { preserved Roman cities, it still keeps many features as its temples, } \\
\text { theaters, streets, forums and tombs. (1) }\end{array}$ \\
\hline & Dibbin & $\begin{array}{l}\text { Dibbin was designated as a National Park in the } 1970 \text { 's; it has spices of } \\
\text { Pine known as the Aleppo pine tree as well as other important spices. (3) }\end{array}$ \\
\hline \multirow[t]{2}{*}{ Ajloun } & Ajloun City & $\begin{array}{l}\text { The stronghold of Qala'at al-Rabadh (Ajloun Castle), a fine example of } \\
\text { medieval Arab/Islamic military architecture. The castle was built between } \\
1184-85 \text { CE by the nephew of Salah Eddin al-Ayyubi, the great Muslim } \\
\text { commander who waged a successful campaign to recover lands lost to the } \\
\text { invading Crusaders. (2) }\end{array}$ \\
\hline & Ajloun Park & $\begin{array}{l}\text { It has spices of Pine known as the Aleppo pine tree as well as other } \\
\text { important spices. (3) }\end{array}$ \\
\hline \multirow[t]{3}{*}{ Karak } & Karak City & $\begin{array}{l}\text { Karak is known for its Crusade Castle (11th Century A.D.), and the } \\
\text { shrines of the Companions of the Prophet (Peace be upon Him). (1) }\end{array}$ \\
\hline & $\begin{array}{l}\text { Wadi el-Mujib } \\
\text { Reserve }\end{array}$ & $\begin{array}{l}\text { Distinguished for its beautiful geological gorge, numerous species of } \\
\text { wildlife, including Nubian Ibex. (3) }\end{array}$ \\
\hline & Southern Ghors & $\begin{array}{l}\text { The Southern Ghor may be associated with the story of Sodom and } \\
\text { Gomorrah. Some scholars see Bab al-Dhra' and Numeira as good } \\
\text { candidates for the biblical Sodom and Gomorrah, other biblical "cities of } \\
\text { the plain-"Admah, Zeboiim and Bela (or Zoar) - may still be waiting to } \\
\text { be rediscovered under the ruins of Early Bronze Age towns as Feifa, Safi, } \\
\text { Khneizirah, and other places throughout the biblical Valley of Salt. (2) }\end{array}$ \\
\hline
\end{tabular}




\begin{tabular}{|c|c|c|}
\hline \multirow[t]{3}{*}{ Tafila } & Dana Reserve & $\begin{array}{l}\text { Dana Reserve is considered as the finest among other natural reserves with } \\
\text { its facilities.The reserve encompasses some of Jordan's most breathtaking } \\
\text { scenery, stretching from the } 1800 \text {-meter-high Sharaa mountains in the east } \\
\text { down to the dunes of Wadi Araba at sea level. Dana Nature Reserve hosts } \\
\text { a wide variety of fauna, including ibex, mountain gazelle, fox, badger, } \\
\text { porcupine, wolf, hyrax, striped hyena, jackal and many others. Numerous } \\
\text { species of birdlife roam the skies of Dana as well. (2) }\end{array}$ \\
\hline & 'Afra & $\begin{array}{l}\text { Known for its hot springs with rich minerals and a temperature of } 45-48^{\circ} \mathrm{C} \text {. } \\
\text { (3) }\end{array}$ \\
\hline & Tafila City & $\begin{array}{l}\text { It was part of the Crusaders' line of defenses. A ruined Crusader fortress } \\
\text { forms part of the landscape of this ancient town. (2) }\end{array}$ \\
\hline \multirow[t]{3}{*}{ Ma'an } & Shobak & $\begin{array}{l}\text { Known for a Crusader fortress, which is named as Mont Realis (Montreal), } \\
\text { it was constructed in } 1115 \mathrm{CE} \text { by Baldwin I, then became under the } \\
\text { control of Ayyubids in } 1187 \mathrm{CE} \text {. Shobak Castle was then restored by the } \\
\text { Mamluks in the 14th century. (2) }\end{array}$ \\
\hline & Petra & $\begin{array}{l}\text { A great Nabataean capital and commercial center, its stunning city is } \\
\text { carved in the red sandstone, and it includes many features as the Siq, the } \\
\text { Treasury, the Monastery, several tombs facades and temples. (1) }\end{array}$ \\
\hline & $\begin{array}{l}\text { Wadi Rum and Ras } \\
\text { en-Naqab }\end{array}$ & $\begin{array}{l}\text { Wadi Rum and Rasen-Naqab are distinguished with their great stone } \\
\text { formations and mountains as well as sand dunes. } \\
\text { Wadi Rum is also home to several Bedouin tribes who live in scattered } \\
\text { camps throughout the area. Climbers are especially attracted to Wadi Rum } \\
\text { because of its sheer granite and sandstone cliffs, while hikers enjoy its vast } \\
\text { empty spaces. (2) }\end{array}$ \\
\hline 'Aqaba & Aqaba City & $\begin{array}{l}\text { Aqaba is Jordan's only beach resort, it is located on the Red Sea and } \\
\text { creates a great place for sports as diving and snorkeling, it homes a great } \\
\text { ecosystem of coral reefs and colorful fish. (1) } \\
\text { With its balmy winter climate and idyllic setting, Aqaba is Jordan's } \\
\text { year-round aquatic playground. In winter, while Amman shivers around } \\
5^{\circ} \mathrm{C}\left(41^{\circ} \mathrm{F}\right) \text {, the temperature hovers steadily at about } 25^{\circ} \mathrm{C}\left(77^{\circ} \mathrm{F}\right) \text { in Aqaba. } \\
\text { (2) }\end{array}$ \\
\hline
\end{tabular}

(1) (Teller 2006)

(2) (http://www.kinghussein.gov.jo/tourism.html, July 15, 2011)

(3) (Samawi 2008)

(4) (al-Majali 2009)

(5) (http//:www.visitjotdan.com, July 15, 2011) 


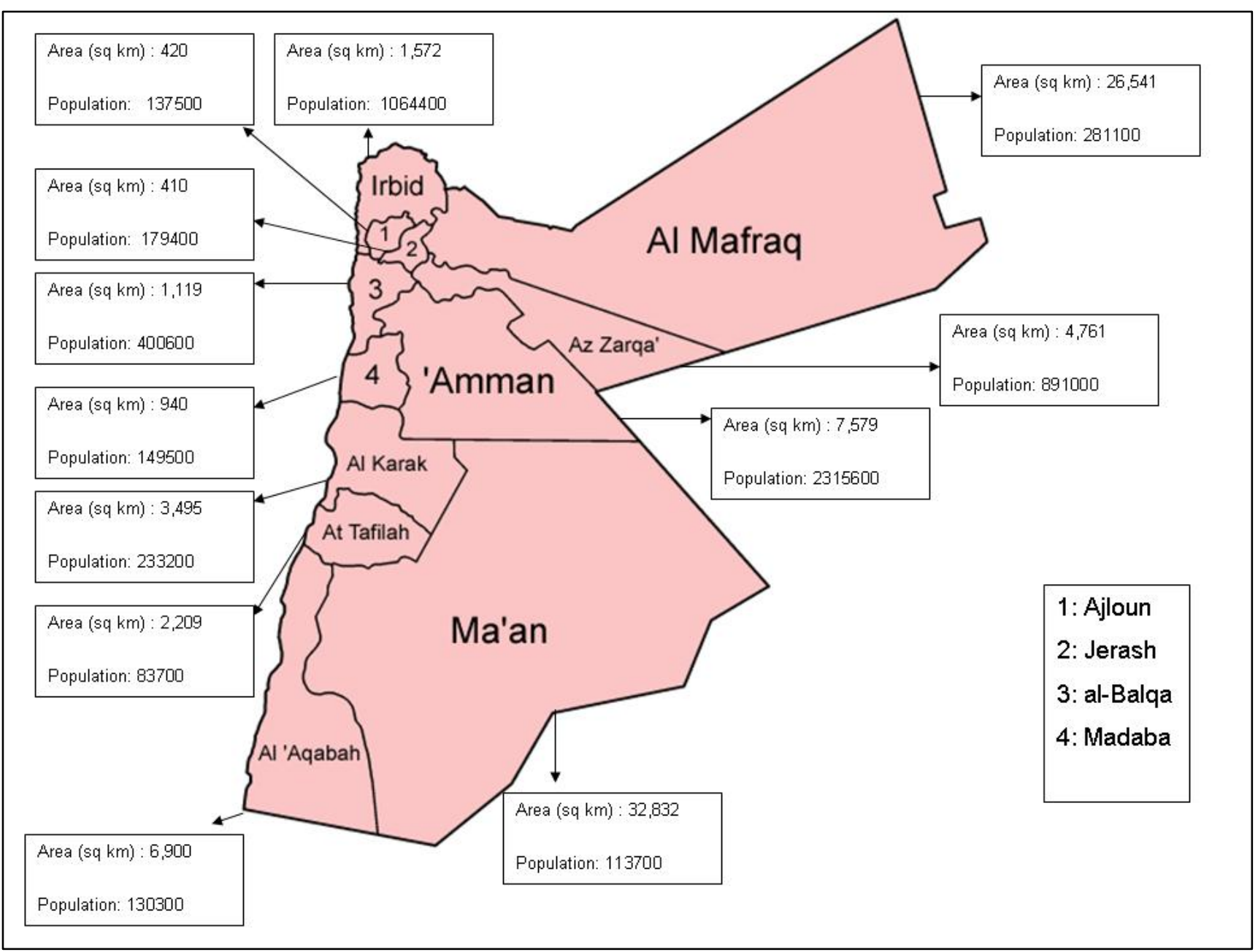

Figure 1. Governorates of Jordan with their Areas and Populations

Information is taken from the report: Jordan in Numbers 2009 - Department of Statistics 


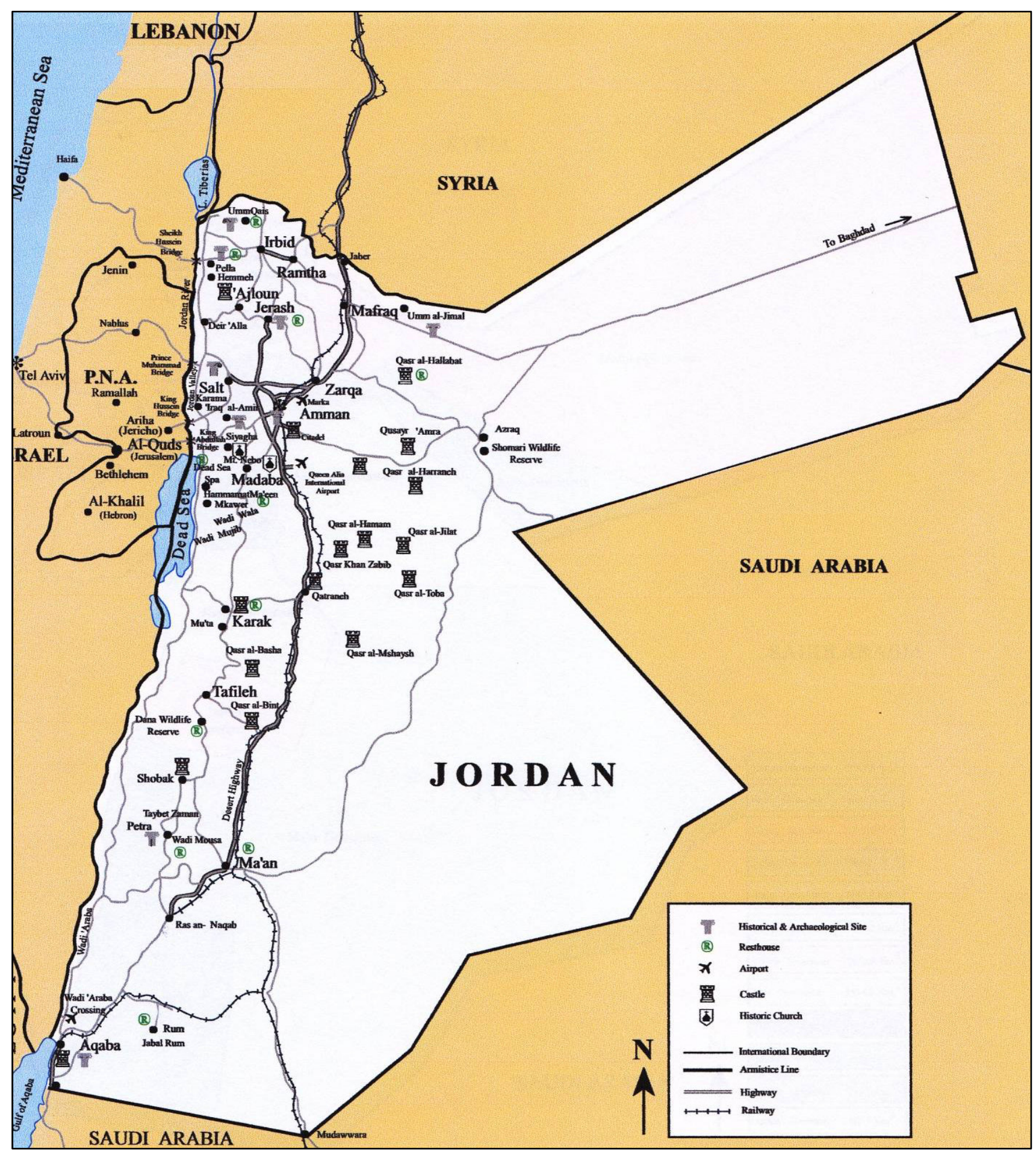

Figure 2. Touristic Map of Jordan

From: http://www.kinghussein.gov.jo/maps_3.html, retrieved on July 17, 2011 